\title{
Energy landscapes of today and tomorrow
}

\author{
Daniela Thrän ${ }^{1,2}$, Erik Gawel ${ }^{1}$ and Dagmar Fiedler ${ }^{1 *}$
}

\section{Keywords: Energy landscapes, Germany's "Energiewende", Renewable energy sources (RES), Sustainable} development, Transition of energy systems

The transition of energy systems toward renewable energy sources (RES) is a key issue for sustainable development. To execute this transformation, a tremendous number of renewable energy provision as well as infrastructure units are necessary. Thus, new energy landscapes will emerge changing energy provision from "energy for space" to "energy from space". Such energy landscapes not only include traditional landscape patterns, but also renewable resource potentials, conversion units and related infrastructure, and also humans being affected by the transition in very different ways: as investors, neighbours, local decision-makers, energy consumers and many more. Likewise, landscapes need to secure manifold functions such as food and material provision, nature protection and recovery. With increasing RES shares, a variety of sustainability challenges have become evident: consideration of the limited land availability by combining material and energy use in agriculture, unlocked potentials to increase local energy efficiency and awareness of concerns associated with the spatioecological and spatio-social effects of RES deployment (land use conflicts, public acceptance, NIMBY). Hence, spatial disutility should be taken into account when using energy landscapes for decentralized energy provision.

Thus, the spatial dimension of the "Energiewende" turns out to be an important issue of further interdisciplinary research. Regional and spatial analyses need to complement the traditional energy systems research. They may contribute to understanding the various drivers of regionally specific RES deployment, identifying regional

*Correspondence: dagmar.fiedler@ufz.de

1 UFZ-Helmholtz-Zentrum für Umweltforschung GmbH, Leipzig, Permoserstrasse 15, 04318 Leipzig, Germany

Full list of author information is available at the end of the article and local patterns, e.g. of environmental impacts, developing and integrating methods of spatial modelling, conducting spatial optimizations and respective conflict management, developing innovative spatially explicit governance concepts.

In light of this, addressing the manifold challenges connected with newly emerging energy landscapes and exploring possible solutions was the focus of the UFZ Energy Days 2018 held in Leipzig from the 24-25 September 2018.

This article collection originates from a selection of papers based upon presentations at the Energy Days. It aims at fostering the exchange between energy research at the UFZ and the national and international scientific community. It is with pleasure and pride that we not only present the carefully reviewed and edited conference papers in this special issue of Energy, Sustainability and Society, but also some recent novel papers from this area, giving our readers an overview of the research activities in this field. To better understand the sustainability hurdles, characterized by more decentralized and consequently more land-intensive production patterns than conventional energy supply systems, this collection provides strategies and concepts for a wide range of scientific disciplines surveyed. Several papers deal with Germany as a case study, where-with the policy effort to bring forward the "Energiewende"-energy landscapes have been created during the last decades.

The topics included in this issue range from wind power to photovoltaic systems [1-3] and from biomass to bioliquids and biofuels for heat, electricity, and transport [4-6], (1A, 3A). They cover the entire innovation process, ranging from scientific research to innovative approaches for technology implementation and the politics of energy landscapes $[5,7](4 \mathrm{~A})$. Furthermore, this

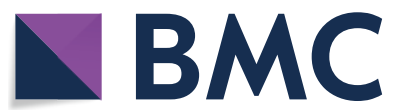

(c) The Author(s) 2020. Open Access This article is licensed under a Creative Commons Attribution 4.0 International License, which permits use, sharing, adaptation, distribution and reproduction in any medium or format, as long as you give appropriate credit to the original author(s) and the source, provide a link to the Creative Commons licence, and indicate if changes were made. The images or other third party material in this article are included in the article's Creative Commons licence, unless indicated otherwise in a credit line to the material. If material is not included in the article's Creative Commons licence and your intended use is not permitted by statutory regulation or exceeds the permitted use, you will need to obtain permission directly from the copyright holder. To view a copy of this licence, visit http://creativecommons.org/licenses/by/4.0/. The Creative Commons Public Domain Dedication waiver (http://creativeco mmons.org/publicdomain/zero/1.0/) applies to the data made available in this article, unless otherwise stated in a credit line to the data. 
edition comments on the societal debate on the benefits and risks of Germany's "Energiewende" and the conservation aspects of future energy landscapes [8,9].

Here, one important contribution deals with combined heat and power production from biomass as one way to efficiently provide renewable heat. Likewise, the gross quantities as well as the economically viable potential of Germany's current bioenergy plant stock is investigated from the viewpoint of supplying renewable heat [6]; whereas, another article focusses on the selection process of different fuel types in detail, where technical aspects such as production, utilization and handling are evaluated by means of a thermodynamic analysis. Based on this analysis, the ecological and economic aspects are assessed to yield a set of recommendations of suitable synthetic transport fuels produced in decentralized plants with $\mathrm{CO}_{2}$ supply from biogas plants [4]; and a third article in this collection quantifies the role that biomethane produced from straw could potentially play in the transport sector. Interestingly, the world's first large-scale industrial plant using the principle of straw mono-digestion is already successfully being operated in Germany, which among others provides a great shortterm contribution to reduce GHG emissions in the transport sector $(1 \mathrm{~A})$.

The focus of some papers is also on Transnational Sustainability Certification for the Bioeconomy (2A), climate targets [10] and carbon and energy footprints [11].

To conclude, we would like very much to seize the opportunity to express our gratitude to our authors for their sustained confidence and also to our valued referees for their tremendous work and generous help in editing this thematic issue. We hope that the readers will enjoy this collection.

Daniela Thrän, Erik Gawel \& Dagmar Fiedler.

\section{Acknowledgements}

Not applicable.

\section{Authors' contributions \\ All authors compiled the editorial. All authors read and approved the final manuscript.}

\section{Funding}

Not applicable.

\section{Availability of data and materials}

Not applicable.

Ethics approval and consent to participate

Not applicable.

\section{Consent for publication}

Not applicable.

\section{Competing interests}

The authors declared that they have no competing interests.
Author details

${ }^{1}$ UFZ-Helmholtz-Zentrum für Umweltforschung GmbH, Leipzig, Permoserstrasse 15, 04318 Leipzig, Germany. ${ }^{2}$ Deutsches Biomasseforschungszentrum (DBFZ), Torgauer Straße 116, 04347 Leipzig, Germany.

\section{The following articles have been positively reviewed and are now revised by their authors:}

(1A) ESSO-D-20-00036R2

Temporal and Spatial Availability of Cereal Straw in Germany - Case Study: Biomethane for the Transport Sector

André Brosowski; Ralf Bill; Daniela Thrän

(2A) ESSO-D-20-00096

Transnational Sustainability Certification for the Bioeconomy? Patterns and Discourse Coalitions of Resistance and Alternatives

Thomas Vogelpohl

(3A) ESSO-D-20-00104R1

A consolidated potential analysis of bio-methane and e-methane using two different methods for a medium-term renewable gas supply in Germany Michael Steubing, Master of Science; Patrick Matschoss; Joachim Pertagnol; Yue Zheng; Bernhard Wern; Martin Dotzauer; Daniela Thrän

(4A) ESSO-D-20-00146

Effects of the German Renewable Energy Act and environmental, social and economic factors: biogas plants adoption and agricultural landscape change

Xueqing Yang; Yang Liu; Daniela Thrän; Alberto Bezama; Mei Wang

Published online: 22 December 2020

References

1. Henze J, Siefert M, Bremicker-Trübelhorn S et al (2020) Probabilistic upscaling and aggregation of wind power forecasts. Energy Sustain Soc 10:15. https://doi.org/10.1186/s13705-020-00247-4

2. Nitsch F, Turkovska O, Schmidt J (2019) Observation-based estimates of land availability for wind power: a case study for Czechia. Energy Sustain Soc 9:45. https://doi.org/10.1186/s13705-019-0234-z

3. Kappner K, Letmathe P, Weidinger P (2019) Optimisation of photovoltaic and battery systems from the prosumer-oriented total cost of ownership perspective. Energy Sustain Soc 9:44. https://doi.org/10.1186/s1370 5-019-0231-2

4. Peters R, Decker M, Eggemann L et al (2020) Thermodynamic and ecological preselection of synthetic fuel intermediates from biogas at farm sites. Energy Sustain Soc 10:4. https://doi.org/10.1186/s13705-019-0238-8

5. Busse M, Siebert R, Heitepriem N (2019) Acceptability of innovative biomass heating plants in a German case study — a contribution to cultural landscape management and local energy supply. Energy Sustain Soc 9:36. https://doi.org/10.1186/s13705-019-0215-2

6. Steubing M, Dotzauer M, Zakaluk T et al (2020) Bioenergy plants' potential for contributing to heat generation in Germany. Energy Sustain Soc 10:14. https://doi.org/10.1186/s13705-020-00246-5 
7. Lintz G, Leibenath M (2020) The politics of energy landscapes: the influence of local anti-wind initiatives on state policies in Saxony Germany. Energy Sustain Soc 10:5. https://doi.org/10.1186/s13705-019-0230-3

8. Ponitka J, Boettner S (2020) Challenges of future energy landscapes in Germany_a nature conservation perspective. Energy Sustain Soc 10:17 https://doi.org/10.1186/s13705-020-00250-9

9. Gauglitz P, Schicketanz S, Pape C (2019) Nature conservation as a driver in wind energy scenarios. Energy Sustain Soc 9:47. https://doi.org/10.1186/ s13705-019-0233-0

10. Wiehe J, von Haaren C, Walter A (2020) How to achieve the climate targets? Spatial planning in the context of the German energy transition. Energy Sustain Soc 10:10. https://doi.org/10.1186/s13705-020-0244-x
11. Kuhn T, Pestow R, Zenker A (2020) On the axiomatic foundation of carbon and energy footprints. Energy Sustain Soc 10:21. https://doi.org/10.1186/ s13705-020-00254-5

\section{Publisher's Note}

Springer Nature remains neutral with regard to jurisdictional claims in published maps and institutional affiliations.
Ready to submit your research? Choose BMC and benefit from:

- fast, convenient online submission

- thorough peer review by experienced researchers in your field

- rapid publication on acceptance

- support for research data, including large and complex data types

- gold Open Access which fosters wider collaboration and increased citations

- maximum visibility for your research: over $100 \mathrm{M}$ website views per year

At BMC, research is always in progress.

Learn more biomedcentral.com/submissions 